\title{
Adaptation of land use based on the assessment of inundation risk in the Kapos Valley, Southwest Hungary
}

\author{
Péter GYENIZSE ${ }^{1}$, Dénes LÓCZY¹, József DEZSŐ¹, \\ ERvin PIRKHOFFER ${ }^{1}$ and MARCIN SŁOWIK ${ }^{2}$
}

\begin{abstract}
Complex river rehabilitation/restoration projects devote equal attention to the improvement of hydromorphological conditions and the neighbouring floodplain environment. Since land use exerts a heavy control on the hydrological cycle of floodplains, land use optimization is a central task in floodplain rehabilitation. In floodplains where large surfaces are temporarily inundated, the optimal allocation of land use classes involves the preservation of wetlands, maintenance of grasslands (meadows and pastures) and forests, and the restriction of arable land to higher ground with the lowest inundation hazard. The detailed mapping of land use against the distribution of soil types and fluvial landforms provides a solid basis for land use optimization. Rehabilitation design is presented in the paper on the example of the Kapos Valley, where inundations in the wet year of 2010 caused great damage to agricultural crops and efforts are directed to better water management (excess water reduction and floodwater retention) on the floodplain. Land use conversions, which are less expensive and easier to implement, are preferred to structural (engineering) solutions.
\end{abstract}

Keywords: floodplain rehabilitation, hydromorphology, paleochannels, peat bogs, Histosols, land use change, Kapos River

Received February 2020; Accepted July 2020.

\section{Introduction}

The deterioration of the hydromorphological properties of river channels and riparian environments in Europe, which is a long-term consequence of river regulation measures (Petts, G.E. et al. 1989), a type of land degradation (Kertész, Á. and Ǩ̌̌ěEK, J. 2019), calls for restoration measures in the case of the majority of rivers (TockNER, K. and STANFORD, J.A. 2002). Now experts agree that - in addition to the hydromorphology of river channels (MADDOCK, I. 1999) - rehabilitation should also extend to floodplain conditions (Brierley, G.J. and Fryirs, K.A. 2008; GWPWMO 2012). The motives of joint river and floodplain restoration include (WhEATON, J.M. et al. 2015):

- aquatic and riparian ecosystem/habitat restoration,

- flood control and floodwater retention,

- floodplain reconnection,

- bank protection through planting arboreal vegetation,

- sediment management,

- improvement of water quality, aesthetic appearance and recreation opportunities. From a geomorphological point of view, improving channel-floodplain connectivity is a key issue in any rehabilitation project (Dezsó, J. et al. 2019). This is a precondition to maintain or enhance biodiversity, produc-

\footnotetext{
${ }^{1}$ Institute of Geography and Earth Sciences, University of Pécs, H-7624 Pécs, Ifjúság útja 6. Hungary. E-mails: gyenizse@gamma.ttk.pte.hu, loczyd@gamma.ttk.pte.hu,pirkhoff@gamma.ttk.tpe.hu

${ }^{2}$ Institute of Physical Geography and Environmental Planning, Adam Mickiewicz University in Poznań, ul. Wieniawskiego 1, 61-712 Poznań, Poland.
} 
tivity, lowering and retarding flood wave peaks, reducing nutrient loads, improving water quality, trapping sediment, promoting groundwater recharge and other ecosystem services (Holmes, N.T.H. 1998).

Worldwide research for the scientific foundation and solution of the problems of river channel and floodplain restoration/rehabilitation has produced a wealth of books and papers written by geomorphologists, hydrologists, engineers, ecologists and their joint teams over the recent decades (NunNALLY, N.R. 1978; National Research Council 1992; Fischer, K.J. 1994; Sear, D. 1994; Kondolf, G.M. and Micheli, E.R. 1995; Hey, D.L. and Philippi, N.S. 1995; Brookes, A. 1996; Brookes, A. and Shields, F.D. Jr. 1996; Fennessy, M.S. and CRONK, J.K. 1997; KauffmAN, J.B. and Beschta, R.L. 1997; Macdonald, K.B. and Weinmann, F. 1997; FISRW 1998; Theiling, CH. 1998; U.S. Department of Commerce 1998; Wissmar, R.C. and Beschta, R.L. 1998; Tockner, K. et al. 1999; Downs, P. and Thorne, C.R. 2000; ZöCKLER, C. 2000; ECRR 2001; Bratrich, C. et al. 2002; Buijse, A.D. et al. 2002; Clarke, S.J. et al. 2003; Hulse, D. and Gregory, S. 2004; Hohausova, E. and Jurajda, P. 2005; Larsen, E.W. et al. 2006; Newson, M.D. and Large, A.R.G. 2006; Kline, M. 2007; DworaK, T. 2008; SCHNEIDER, E. 2010; WWF International 2010; RonI, P. and Beechie, T. 2013; Guerrin, J. 2014; KiedrzyŃsKa, E. et al. 2015; Hein, T. et al. 2016; Opperman, J.J. et al. 2017).

As a theoretical background to the issue the classical concept of 'design with nature' (McHARG, I. 1969), which also includes landscape ecological aspects, can be detected. In addition to bringing planning in harmony with natural processes, sustainability is another foremost requirement, as it is common for any other planning task. Enhancement of riparian ecosystems involves raising the value of habitats for wildlife, increasing plant or community diversity (MANCI, K.M. 1989), also preserving or even increasing landscape (land use) diversity.

Today experiences on floodplain restoration are available for assessment from all parts of the world and all geographical environments (Moss, T. and Monstadt, J. 2008). Using physical (channel and floodplain morphology, sediment, flow, water quality [temperature and nutrients]) and biological indicators (fish, invertebrates, and aquatic and riparian plants), Roni, P.et al. (2019) evaluate the effectiveness of various floodplain restoration approaches on the basis of 180 papers. BERNHARDT, E.S. et al. (2005) report about a comprehensive database of more than 37,000 river restoration projects of various scale across the United States. The most common objectives were to enhance water quality, manage riparian zones, improve in-stream habitat, allow fish passage, and stabilize stream banks. Only 10 per cent of project records, however, mention continuous project monitoring. This means that the ecological effectiveness of restoration activities cannot be evaluated in the majority of cases.

In the first stage the morphological floodplain and, within that, the floodway zone (i.e. the active floodplain - BogáRDI, I. and BALOGH, E. 2014), allowed for inundation during floods and reserved for fluvial processes, should be delimited. The theoretical concepts to be applied in this delimitation are the geomorphic recovery potential (BRooks, A.P. and Brierley, G.J. 2004; Fryirs, K.A. and Brierley, G.J. 2016), the streamway or erodible river corridor (PIÉgAy, H. et al. 2005), dyke set-back (in the German literature: Deickrücklegung) (FISCHER, K.J. 1994), and 'room for the river' (Rohde, S. et al. 2006). The essence of these concepts is that free channel migration should be allowed within a zone (corridor) defined by human structures or agricultural land or any other land use types which have to be protected from bank erosion and flooding. Allowing free channel migration would spare considerable costs of water management and flood defence (PiÉGAy, H. et al. 2005). The reconstruction of river history is indispensable for planning restoration, to define realistic goals of restoration actions (BRIERLEY, G.J. et al. 2002; SŁOWIK, M. 2013).

While in the floodway flood control is of decisive significance (ÖKO Rt., FÖMI and VÍZPART Kft. 2000; APFM-WMO 2017), over 
the protected portions of the morphological floodplain a wide range of land use classes can be present. Floodplain soils have long been used for arable farming, horticulture and grazing with increasing intensity (Posthumus, H. et al. 2008; XIE, H.L. et al. 2019), while lower-lying wetlands are valuable for water management, forestry, tourism and nature conservation purposes (WWF 2004). The broad range of floodplain land uses makes the setting of rehabilitation objectives difficult. Rehabilitation can only be successful if it is designed parallel to an incessant process of reconciliation of interests in various circles of stakeholders (see e.g. BALL, T. 2008).

Intensive agricultural use of floodplains has led to environmental problems. For instance, reclaimed peatlands have suffered deterioration through oxidation of peat and the related ground subsidence (Verhoeven, J.T.A. and SETTER, T.L. 2010). In spite of their significance for landscape ecology and nature conservation, wetlands continue to be under threat of being drained and reclaimed. Agriculture is the most important non-point source of water pollution and, in addition to their hydrological role (Bullock, A. and Acreman, M.C. 2003), the buffering capacity of wetlands is vital for the efficient functioning of floodplains (Fennessy, M.S. and Cronk, J.K. 1997).

A new aspect of the optimization of floodplain land use is related to climate change (Didovets, I. et al. 2019; Fehér, Z.Zs. and RAKONCZAI, J. 2019). In addition to catchment management, river runoff, the temporal and spatial patterns of floods and droughts increasingly depend on the changing climate (KLUG, H. 2016). Rainfall distribution tends to be the sole control of the regimes of rivers (like the Kapos in Southwest Hungary) which only drain low hilly regions with negligible winter snow cover. Extreme floodplain inundations closely correlate with extreme rainfall events (such as in spring and autumn of 2010). It has only recently been incorporated into water management policy that surplus water has to be stored in the floodplain to mitigate ensuing drought hazard (SomLyódy, L. 2011).
A land use analysis from nature conservation aspect (ÖKO Rt., FÖMI, VÍZPART Kft. 2000) and feasibility studies of development (Gergely E. et al. 2000) have considered rehabilitation needs for the Kapos catchment. These studies, however, failed to investigate all aspects of a complex transformation of the floodplain. The conclusions drawn from both our hydrogeomorphological studies (the description of embayments and gaps, valley and floodplain asymmetry, channel reconstructions) and landscape ecological assessments supply further information to the achievement of the rehabilitation goals (Lóczy, D. 2013).

\section{Objectives}

In order to identify the tasks of floodplain rehabilitation, within the complex hydromorphological and landscape ecological research project of the Kapos floodplain the following questions have been raised (Lóczy, D. 2013): - How serious is the flood hazard in the morphological floodplain?

- How do the landscape patterns of the broader catchment, the protected floodplain (its wetlands) and the active floodplain compare with each other?

- What is the land capability of the individual floodplain sections? To what extent does the actual land use pattern provide ecosystem services? What would be an optimal land use pattern like and how to achieve it?

- How can the rehabilitation potential be rated for the Kapos floodplain?

The present paper does not cover all of these issues. It is restricted to those which are relevant for land use optimization, i.e. assessments of flood hazard, land capability, land use pattern and rehabilitation potential.

\section{Study area}

In Hungary morphological floodplains extend over 30 per cent of the county's territory. In lowland areas huge expanses of land are affected by excess water hazard (PÁLfAI, I. 2009). 
They are vulnerable as almost 3 million people live there in 400 settlements, and 200 major industrial plants, 32 per cent of the railway network, and 15 per cent of public roads are also located in these areas (SomLyódi, L. 2011).

The medium-sized catchment of the Kapos River covers 3,295.4 km² in the South Transdanubian Hills region and the Mecsek Mountains (Lóczy, D. 2013 - Figure 1). The Kapos River is 112.7 km long. The morphological floodplain (without that of the tributaries) extends over $104.2 \mathrm{~km}^{2}$, which makes up 3.3 per cent of the total catchment area. Consequently, runoff from the hilly parts of the catchment is concentrated in an area of limited extension.

The source of the Kapos is south of the village Kiskorpád at ca. $180 \mathrm{~m}$ above sea level and its confluence with the Sió Canal (the outflow of Lake Balaton to the Danube) is at 96 m elevation.

The upper Kapos catchment has a sub-atlantic climate with mean annual temperature sligthly above $10^{\circ} \mathrm{C}$ and annual precipitation of $680-720 \mathrm{~mm}$, while the eastern part is subcontinental $\left(10.8-11.0^{\circ} \mathrm{C}\right.$ and $\left.650-690 \mathrm{~mm}\right)$. The water regime shows low-water stages in August-early September and high water most often in March (caused by snowmelt in the hills) (Table 1). Most of the other extremes in

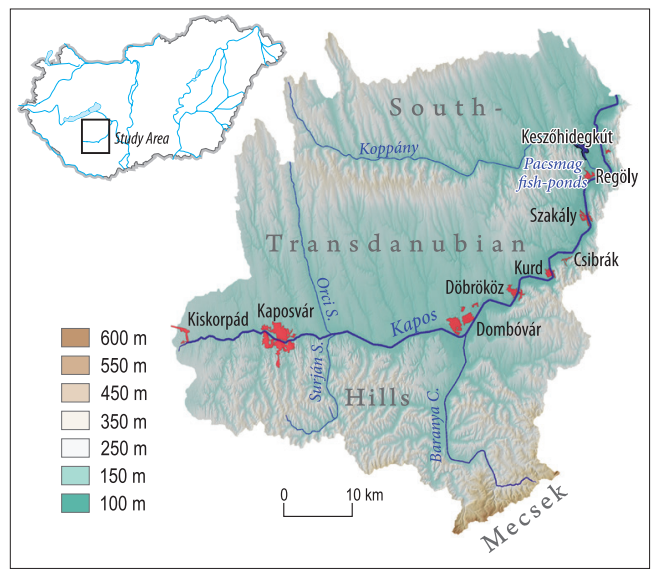

Fig. 1. Topography of the Kapos catchment. Source: DEM with 10-metre resolution, DDVÍZIG. the regime are due to summer showers. In the embayments downstream of the town of Dombóvár rainy weather can raise groundwater levels rapidly and create extensive temporary waterlogging (GERGELy, E. et al. 2000).

As a direct corollary of regional tectonics, a remarkable asymmetry and remarkably regular alternation of floodplain constrictions (gaps) and relatively wide embayments are typical for the geomorphology of the middle and lower sections of the Kapos Valley. In the loess landscape a low-energy meandering planform evolved superimposed over landforms of coarser alluvia inherited from a high-energy Pleistocene braided river system (SŁOwIK, M. et al. 2020).

At the mouths of tributary valleys small and very flat alluvial fans have accumulated. In the abandoned channels and backswamps of the embayments peat bogs formed in historical times. Poor drainage was only improved by river flow regulation (BENCzE, G. 2000). The inventory of peatlands in Hungary, compiled in the 1970s, recorded former peat bogs of 851 ha area $\left(9,140,000 \mathrm{~m}^{3}\right.$ peat reserves) in the abandoned channels and backswamps of the Kapos and its tributaries (DöмsöDI, J. 1980). Flow regulation and the accompanying floodplain drainage induced peat decomposition. Fibric Histosols (fibrous peat) have been humified to Hemic Histosols (mucky peat, muck) and, finally, to Humic Histosols (earthy peat or 'black earth'). Along the headwaters fibrous peat is found in 5-6 $\mathrm{m}$ thickness, while in the lower valley segment of the valley muck and humified peat beds occur in $1 \mathrm{~m}$ thickness (Gergely, E. et al. 2000). On fluvial sand deposits Fluvisols are predominant.

\section{Methods}

The steps followed in the present research were the following:

- delineation of the morphological floodplain of the Kapos River;

- reconstruction of a historical drainage pattern which had existed before river regulations started; 
Table 1. Basic hydrological data on the watercourses of the Kapos system, 1995-2005

\begin{tabular}{|c|c|c|c|c|c|c|c|}
\hline \multirow[t]{2}{*}{ Stream } & Length & Catchment & Site of gauge & $\begin{array}{l}\text { Low } \\
\text { flow }\end{array}$ & $\begin{array}{l}\text { Mean } \\
\text { flow }\end{array}$ & $\begin{array}{l}\text { Median } \\
\text { high } \\
\text { flow }\end{array}$ & $\begin{array}{l}\text { Absolute } \\
\text { record } \\
\text { flow }\end{array}$ \\
\hline & \multicolumn{2}{|c|}{$\mathrm{km}$} & river $\mathrm{km}$ & \multicolumn{4}{|c|}{$\mathrm{m}^{3} \mathrm{~s}^{-1}$} \\
\hline Kapos & 112.7 & 3126.4 & $\begin{array}{l}\text { Kaposvár-Fészerlak, } 86.0 \\
\text { Kurd, } 43.7 \\
\text { Pincehely, } 7.9\end{array}$ & $\begin{array}{l}0.055 \\
1.000 \\
1.040\end{array}$ & $\begin{array}{l}1.724 \\
6.160 \\
6.190\end{array}$ & $\begin{array}{r}7.54 \\
46.80 \\
42.40\end{array}$ & $\begin{array}{r}45.5 \\
130.0 \\
174.0\end{array}$ \\
\hline Koppány & 63.6 & 747.1 & Tamási, 14.5 & 0.160 & 1.210 & 30.90 & 77.0 \\
\hline Baranya Canal & 38.0 & 606.5 & Csikóstőttős, 3.2 & 0.120 & 1.830 & 68.00 & 110.0 \\
\hline Orci Stream & 27.2 & 133.1 & Orci, 5.1 & 0 & 0.550 & 27.00 & 27.0 \\
\hline Surján Stream & 23.8 & 112.8 & Szentbalázs, 4.5 & 0 & 0.290 & 10.30 & 37.0 \\
\hline
\end{tabular}

Sources: Hydrological Yearbooks 1997-2008; DövÉNYI, Z. 2010

- survey and assessment of present-day land use based on remote sensing information;

- mapping floodplain soils and landforms;

- assessment of inundation hazard;

- determination of criteria for and estimation of rehabilitation potential;

- identification of needs for land conversion and design of an optimal land use pattern. The morphological floodplain of the Kapos River was delimited using the Multiresolution Valley Bottom Flatness (MrVBF) index (Gallant, J.C. and Dowling, T.I. 2003). The algorithm identifies several assumptions referring to the flatness and low elevation of floodplains and their dependence on terrain pattern properties. The computing algorithm of the MrVBF index is compatible with the ArcInfo GRID module. The valley bottoms are delimited at a range of scales. A given site is considered to belong to valley bottom at a given scale if it is sufficiently low and flat at that scale. At each step of the procedure, in the newly generated DEM cell size increases by a factor of 3, and the slope threshold reduces by a factor of 2. (For more details see Lóczy, D. et al. 2012). The floodplain reconstruction based on the MrVBF index was compared with the delimitation relying on the interpretation of the Second Military Survey map sheets (from 1857-1859). The land use class 'wet meadow' approximately coincides with the floodplain, where no arable fields were cultivated at that time. Another opportunity for correction was provided by aerial photographs from the time of the 2005 flood.
Archive maps were also used to detect the positions of river channels before flow regulations. Occasionally several river branches were active in the same period. No single archive map could supply us with this information - a joint interpretation of several sources had to be employed: georeferenced map sheets of the First (1783-1784), the Second (1857-1859) and the Third Military Survey (1881-1882), a 1:10,000-scale topographic map (revised in 1999), aerial photographs of the General Directorate of Water Management (OVF) for the 2005 and 2010 floods and Google Earth maps for the identification of surfaces (paleochannels) then covered with excess water. The analyses were made in ArcGIS version 9.2 Spatial Analyst environment. In addition, paleochannels could be identified on the basis of their (peaty) soils shown on the soil map.

To prevent the transport of nutrients to water bodies, the optimal land use types along the floodplain margin are a forest zone, tree rows or grassed strips (CRONK, J.K. 1997; and Rogger, M. et al. 2017). The continuity of these land use classes within a 100-metre wide zone was also assessed from the land use map.

In the framework of the soil survey a total of 40 soil profiles were analyzed. The sites of soil pits and auger holes were selected on the basis of microtopography (as reflected by the DEM). Thus, the surveyed soil profiles are assumed to represent all classes of fluvial landforms in the floodplain. Soil samples were analysed in the Lovász György Physical 
Geographical Laboratory of the Faculty of Sciences, University of Pécs, for grain size distribution, mineral composition, organic matter content and for type and content of carbonates. Grain size distribution was established by the Fritsch Analysette A22_32 laser equipment in the measurement range of 0.3 to 300 $\mu \mathrm{m}$. Index values were determined according to the Hungarian standard MSZ08 0206/1-78, while water soluble salts were measured (in $\mathrm{m} / \mathrm{m}$ salt $\%$ ) according to the Hungarian standard MSZ08 0206/2-78. Carbonate contents were determined by Scheibler's calcimeter (German standard DIN 18 129). For the mineral composition of soil samples a Shimadzu TGA 50 thermogravi-meter was applied, which measures mass changes caused by decomposition reactions in proportion to rising temperature. Samples of $40 \mathrm{mg}$ mass each were analysed at $10{ }^{\circ} \mathrm{C} \mathrm{min}^{-1}$ heating rate.

The soil subtypes and varieties were first identified in the Hungarian genetic classification system and then referred to the WRB system. The information from point-like soil surveys was extended based on the distribution pattern of fluvial landforms. Ground Penetrating Radar (GPR) surveys were performed across abandoned Kapos channels in embayments (SŁowıK, M. et al. 2020) to reveal the internal structure of paleochannels and backswamps supplemented with 30 auger holes and corings. To estimate the age of the palaeomeanders, ${ }^{14} \mathrm{C}$ dating was carried out in the Poznań Radiocarbon Laboratory (Poland), for 20 samples of terrestrial plant macrofossils and charcoal pieces using Accelerator Mass Spectometry (AMS).

For the assessment of rehabilitation opportunities, water retention potential was used as the principal criterion. For floodplains three types of retention capacity are usually identified (Dostal, T. et al. 2012):

- Water retention capacity of soils - some deposits (sands) are sufficiently porous to absorb a high proportion of floodwater.

- Passive retention capacity of the floodplain - retention in backswamps, abandoned channels or other depressions of some embayments.
- Transformation effect of river channels and their floodplains - assuming that during overbank flow current velocity drops and, thus, the flood wave is decelerated.

The floodwater retention capacity of the Kapos floodplain was estimated from soil hydrological data. Maximum water capacity and storage capacity (the amount of water released from a unit volume of soil by gravitation) was rendered to the main horizons of typical soil profiles. Passive (surface water) retention capacity was estimated from the DEM and added to soil retention. Although estimations of the rate of flood peak dispersion and propagation along the river-floodplain corridor would have been useful for restoration planning, such data were not available. Therefore, flood wave deceleration was ignored in the calculations.

The classes of rehabilitation potential (mapped for the Danube by WWF International 2010 or for the Transboundary Biosphere Reserve Mura-Drava-Danube by Schwarz, U. 2013) express the degree to which connectivity between sites with high water retention potential and the main river channel can be restored. The potential varies with the floodplain segments identified (for the Kapos: Lóczy, D. et al. 2012). The engineering measures of floodplain restoration (Buijse, A.D. et al. 2002) are not treated here.

The alternatives of restoration/rehabilitation are referred into one of three groups (Sмiтh, M.P. et al. 2008): 'no action', passive or active intervention (Table 2). The 'no action' alternative means that the channelized river is capable of restoring its close-to-natural conditions over the long term without any human assistance. In this case the recovery potential is high. From such a strategy, however, it cannot be expected that a fully natural state is restored - not even in the very long term. Active rehabilitation aims at 'products' (creating landforms and vegetation/land use assumed to be more favourable), while passive (or non-structural) rehabilitation strives at generating processes which are expected to indirectly lead to favourable conditions later in the future (WheAton, J.M. et al. 2019). 
Table 2. Comparison of the three rehabilitation approaches*

\begin{tabular}{l|l|l|l}
\hline $\begin{array}{l}\text { Recovery } \\
\text { potential }\end{array}$ & $\begin{array}{c}\text { General } \\
\text { approach }\end{array}$ & \multicolumn{1}{|c|}{ Strategy } & \multicolumn{1}{c}{ Example for intervention } \\
\hline High & 'no action' & $\begin{array}{l}\text { No intervention in the hope of natural re- } \\
\text { covery, i.e. that the river itself obliterates } \\
\text { the consequences of minor disturbances. }\end{array}$ & $\begin{array}{l}\text { Disturbances of natural origin (such as } \\
\text { floods) lead to an equilibrium state over } \\
\text { the long run. }\end{array}$ \\
\hline Medium & passive & $\begin{array}{l}\text { After implementing flood control meas- } \\
\text { ures, the free response of river channel } \\
\text { is allowed and promoted. }\end{array}$ & $\begin{array}{l}\text { Purchasing land in the riparian zone by } \\
\text { the state to secure space for meander } \\
\text { development. }\end{array}$ \\
\hline Low & $\begin{array}{l}\text { Correction of the alignment of the } \\
\text { channelized river in order to establish } \\
\text { a stable channel, incorporating passive } \\
\text { procedures. }\end{array}$ & $\begin{array}{l}\text { New channel alignment, bank rein- } \\
\text { forcement using natural methods but } \\
\text { allowing space for the 'fine tuning' of } \\
\text { flow pattern. }\end{array}$ \\
\hline
\end{tabular}

${ }^{*}$ Modified after Sмітн, M.P. et al. 2008.

For mapping the extent of inundation during floods, an important information for floodplain rehabilitation and land use optimization, was estimated from aerial photographs taken by the Pécs Aeroarchaeology Theca (Photo 1). The distribution of inundated areas was confirmed by satellite image interpretation (RAKONCZAI, J. et al. 2003), using the image first available after the most recent major flooding of autumn 2010 (from band 6 of the Landsat-7 [ETM+] image for 24 September 2010). It shows the actual distribution of pixels where reflectance was predominantly controlled by water surface. (Reflectance was calibrated for fish-ponds in the study area.) The drainage network was superimposed

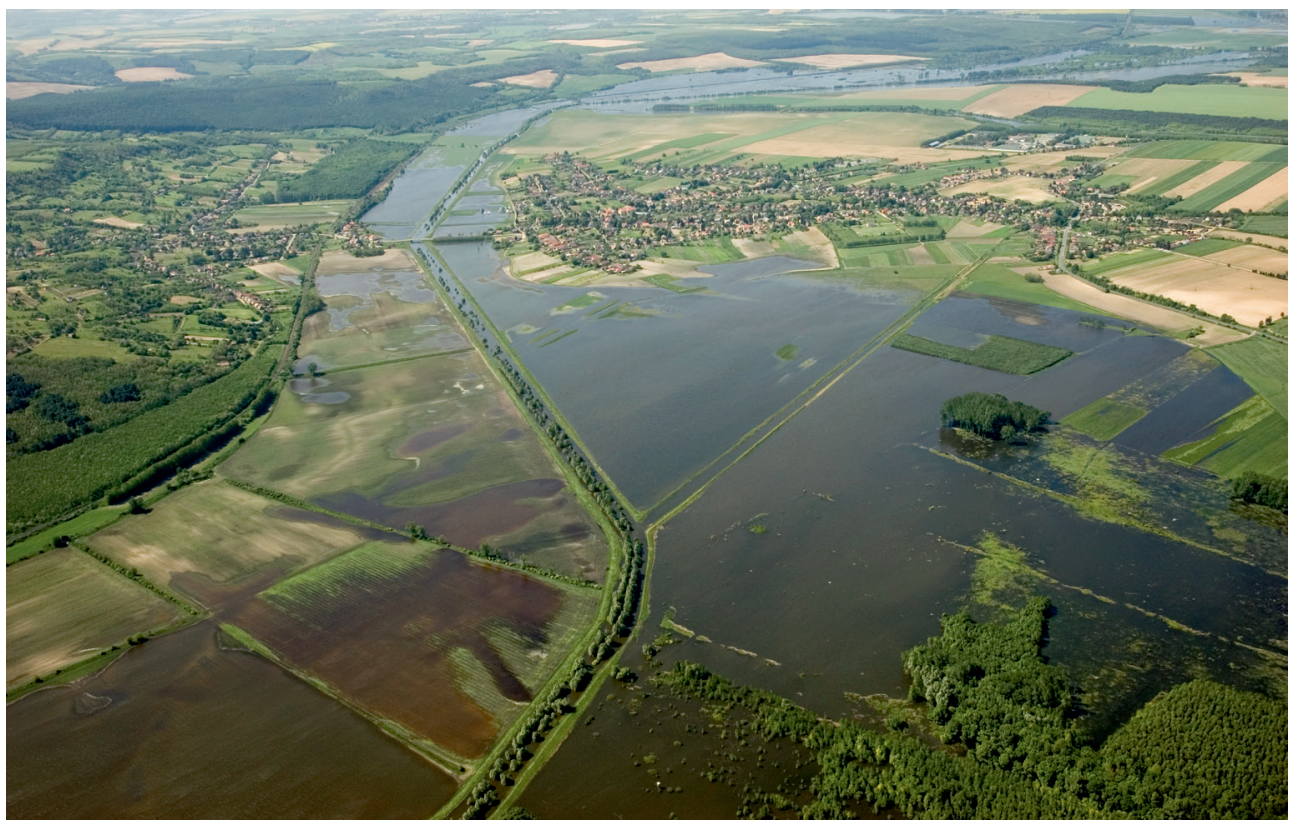

Photo 1. The Döbrököz area on an aerial photograph (May 2010) taken by the Pécs Aeroarchaeology Theca (Photo by Szabó, M.) 
on the image from the Hungarian Water Management Database (although with substantial allocation error). The smoothed envelope curve embraces all 'water' pixels and provides at least an approximation potentially waterlogged areas. (This kind of reconstruction, however, only shows a partial picture of excess water inundation. Also areas with groundwater table immediately [less than 20 $\mathrm{cm}$ ] below the surface could have been rightfully included among those stricken by excess water - RAKonCZAI, J. et al. 2003.)

The need for land conversion was identified based on a rapid land capability assess- ment with limited data requirement ('practical land assessment' DömsöDI, J. 2011). It only covers eight (complex) components of land quality in a weighted system (Table 3). According to their productivity, the genetic soil types which occur in floodplains are referred into four classes (numbers III and IV are only usable for meadow and reed economy). The assessment was supplemented with land suitability considerations, where a crucial criterion was how long the individual crops can tolerate spring-early summer inundation without severe reduction in yields (Petrasovits, I. and Balogh, J. 1975 - Table 4).

Table 3. Main factors in land evaluation for practical agricultural purposes*

\begin{tabular}{l|l|c}
\hline Number & \multicolumn{1}{c}{ Factor of land quality } & \multicolumn{1}{c}{\begin{tabular}{c}
\multicolumn{1}{c}{ Maximum score of } \\
agricultural site quality
\end{tabular}} \\
\hline 1 & $\begin{array}{l}\text { Topography (topographic position, slope, mean depth to ground- } \\
\text { water table, erosion and deflation hazards) } \\
\text { Local climate (exposure) }\end{array}$ & 18 \\
\hline 2 & $\begin{array}{l}\text { Genetic soil type (obtained from the map 'Genetic soil types of } \\
\text { Hungary') }\end{array}$ & 9 \\
\hline 3 & Chemical properties of topsoil (pH, carbonates, salinity) & 9 \\
\hline 4 & $\begin{array}{l}\text { Physical soil type (specific resistance) } \\
\text { Soil structure }\end{array}$ & 18 \\
\hline 5 & $\begin{array}{l}\text { Properties reducing subsoil quality (water conductivity, soil } \\
\text { properties causing deficiency in productivity down to 150 depth) }\end{array}$ & 9 \\
\hline 7 & $\begin{array}{l}\text { Depth of humus layer, } \\
\text { Soil depth }\end{array}$ & 9 \\
\hline Total & Suitability for arable and other land uses & 18 \\
\hline
\end{tabular}

*Revised after DömsöDI, J. 2011.

Table 4. Inundation tolerance of agricultural crops widely grown in Hungary measured in percentage of yield loss*

\begin{tabular}{|c|c|c|c|c|c|c|c|c|}
\hline \multirow{3}{*}{ Crop } & \multicolumn{8}{|c|}{ Duration of inundation, days } \\
\hline & \multicolumn{4}{|c|}{ March } & \multicolumn{4}{|c|}{ April } \\
\hline & 3 & 7 & 11 & 15 & 3 & 7 & 11 & 15 \\
\hline Winter cereals & 5 & 15 & 30 & 50 & 10 & 25 & 40 & 70 \\
\hline Maize & - & - & - & - & 20 & 80 & 100 & 100 \\
\hline Sunflower & - & - & - & - & 10 & 20 & 50 & 80 \\
\hline \multirow{3}{*}{ Sugar-beet } & 10 & 50 & 100 & 100 & 10 & 50 & 90 & 100 \\
\hline & \multicolumn{4}{|c|}{ May } & \multicolumn{4}{|c|}{ June } \\
\hline & 3 & 7 & 11 & 15 & 3 & 7 & 11 & 15 \\
\hline Winter cereals & 20 & 40 & 70 & 100 & 20 & 50 & 80 & 100 \\
\hline Maize & 10 & 50 & 80 & 100 & 10 & 40 & 75 & 100 \\
\hline Sunflower & 15 & 30 & 80 & 100 & 20 & 40 & 80 & 100 \\
\hline Sugar-beet & 10 & 50 & 90 & 100 & 10 & 40 & 90 & 100 \\
\hline
\end{tabular}

*After Petrasovits, I. and Balogh, J. 1975. 
Enduring waterlogging primarily precludes arable farming, while tree plantations and grazing lands are tolerant for inundation of several weeks' duration. In the case of maize even one-week duration means 80 per cent yield loss. Sunflower is also somewhat less sensitive to inundation in May.

\section{Results and discussion}

The map reconstruction of the groundplan of the Kapos paleochannel system presents an intricate low-energy anastomosing/braiding pattern with some meandering channels (Figure 2). There is a zone along the floodplain margin where paleochannels could not be mapped. This fact can be explained by intensive sheetwash from the neighbouring slopes onto the floodplain. The washed-down loess deposits obliterate the traces of paleochannels from the surface and also raise the elevation of the ground surface. This has important implications for land use (see later).

Creating new Kapos channel sections requires space and it is only feasible in the broadest embayments. Previous rehabilita-

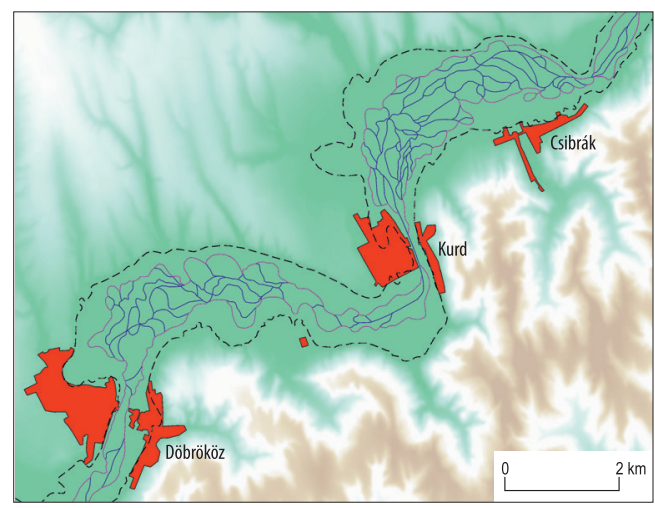

Fig. 2. Reconstruction of old Kapos channels in the Döbrököz and Kurd-Csibrák embayments (38-51 river $\mathrm{km}$ ) for the early $19^{\text {th }}$ century (drawn by GYENIzse, P. after information from military survey maps). The black dashed line indicates the boundary of the morphological floodplain and the magenta enveloping lines the channels farthest away from the valley centre line. tion proposals for the Kapos floodplain (for instance, Gergely, E. et al. 2000) suggested channel rearrangements (primarily along the Kurd section) to reduce flood hazard. From a purely geomorphological viewpoint, the establishment of several more or less parallel, meandering channels would be an optimal solution for the restoration of a close-to-natural drainage pattern. This can be achieved through taking advantage of the infilled channels still traceable in microtopography and returning to the $19^{\text {th }}$-century regulation plans, which relied on several lateral canals running along the floodplain margins (BEszéDEs, J. and Herman, J. 1829). Such marginal canals could have some benefits even today:

- they conduct away the flash floods generated on tributary streams;

- dissipate the energy of floods;

- isolate the main channel from the nonpoint pollution of agricultural (or accident) origin (see KRONVANG, B. et al. 2004);

- raise groundwater levels even during dry spells.

A detailed reconstruction of paleochannels was conducted by SŁowıк, M. et al. (2020) for the Kapos-Koppány confluence area. They discovered that single-thread meandering planform was active here since the Late Glacial. This low-energy meandering system was characterized by elongate bends with circular pools near apexes. The meanders evolved through oblique accretion, periods of cut-offs in the Late Glacial, and periods of flow discontinuation during the last 4,000 years (cf. SŁowıк, M. et al. 2020).

Are there real opportunities for dyke relocation (ECRR 2001; Clarke, S.J. et al. 2003) in the Kapos Valley? In the densely built-up upper (Kaposvár-Dombóvár) section any channel translocation would be difficult to implement. Downstream, however, in the broad embayments, where the floodplain rehabilitation potential is higher, they are worth of consideration. In the reach between settlements Szakály and Regöly (river km 27-24), dyke relocation seems to be an obvious and low-cost solution. Here dyke construction was unnecessary in the first place since parallel with the dyke, at ca 
$50 \mathrm{~m}$ distance, a relatively high natural levee of sand rises (Photo 2). The functioning of this landform of natural origin as a flood-control structure would also improve the water supply of the floodplain. To the space between the present dyke and the natural levee (which was probably also deepened as a navvy pit from where material for dyke construction was gained) the active floodplain could be extended. The bank zone being suitably landscaped, it would add to the wetlands of the Kapos Valley, store water during floods and create valuable habitats for nature conservation.

Using soil survey information, a remarkable soil water retention capacity was identified. The calculations resulted in a total maximum dynamic water capacity of $6,139,000 \mathrm{~m}^{3}$ for the $4.45 \mathrm{~km}^{2}$ area of embayments. Out of this amount 2,251,000 $\mathrm{m}^{3}$ can be pumped out.

The assessment of the rehabilitation potential is primarily based on the opportunities for floodwater retention and flood risk reduction (see Lóczy, D. 2013). The results show that the rehabilitation proposals should focus on floodplain segments IV and V (Figure 3), where a combination of a range of interventions could improve the ecological conditions of the floodplain. Rehabilitation potential is relatively high along the reach around the confluence of the most important tributary, the Koppány (although the channelized rivers are deeply in-sized). The riverine wetlands can only be restored if groundwater levels are raised. The silt layers of low permeability in this floodplain section favours water retention after floods. (By sporadic measurements typical grain size of suspended load was found to range from $0.033 \mathrm{~mm}$ to $0.079 \mathrm{~mm}$ with a median value of 0.040 mm - cited by BogÁRDI, J. 1971). However, it is doubtful whether this would be sufficient to maintain the wetlands during summer drought.

The constructed wetlands to be formed in the confluence area could be connected to the already existing Pacsmag fish-ponds, an important bird refuge, Ramsar site and Nature Reserve of 487 ha area. The constructed wetland would also increase the aesthetic value of the floodplain landscape.

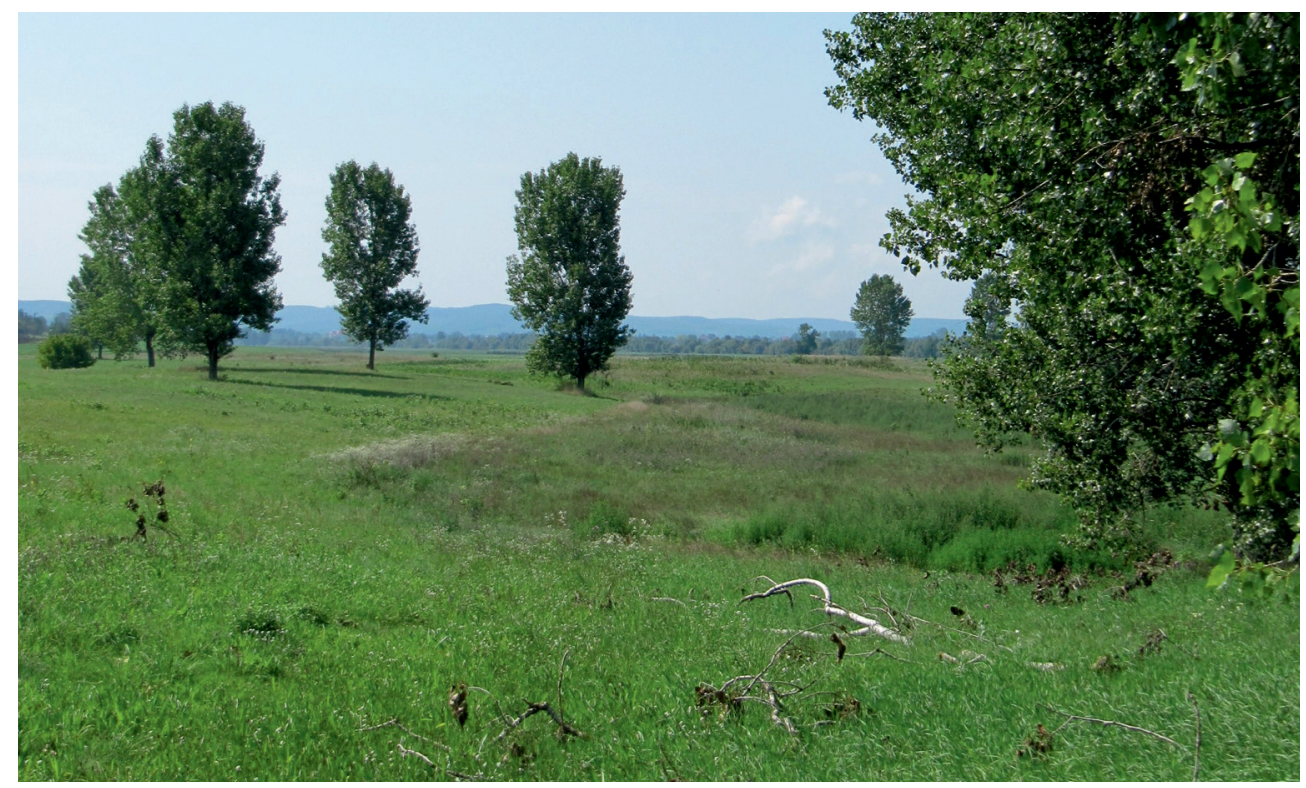

Photo 2. The natural levee at Szakály with a row of poplars on the right bank of the Kapos River (Photo by Lóczy, D.) 


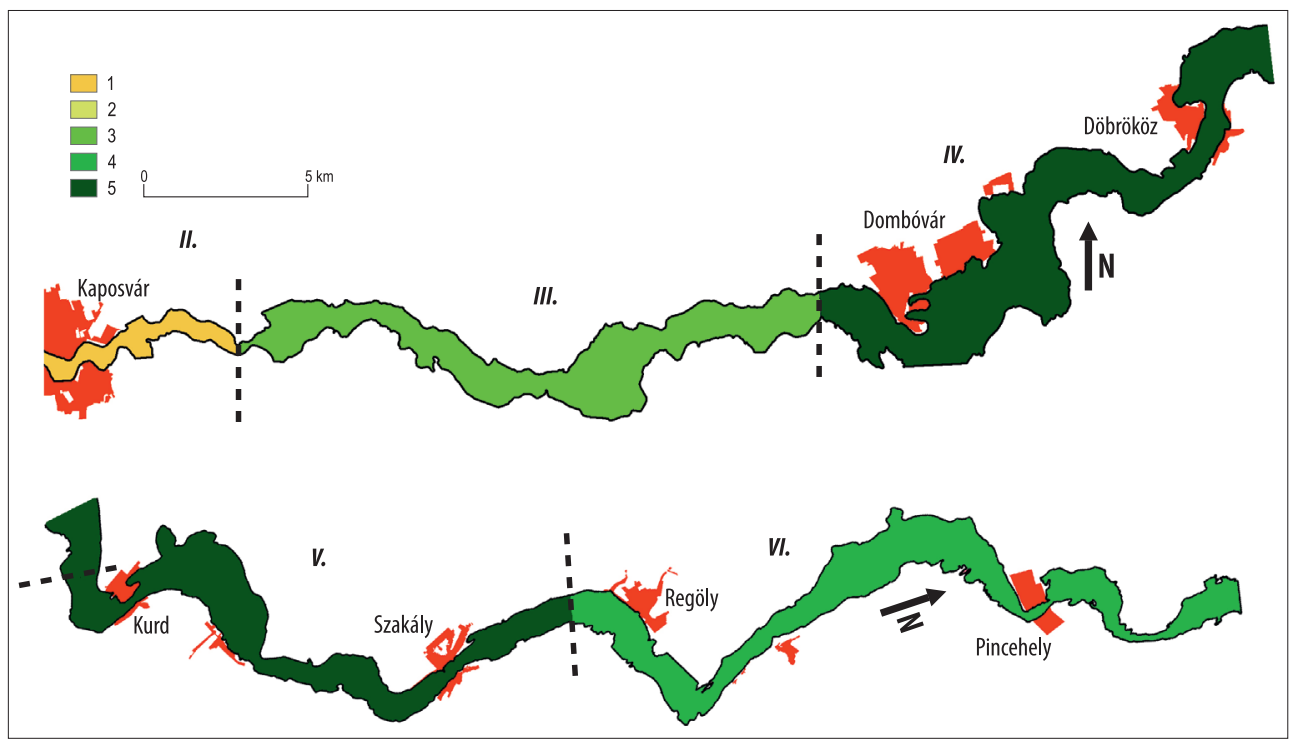

Fig. 3. Rating the rehabilitation potential of the various hydromorphological sections of the Kapos floodplain (by Lóczy, D.). The floodplain sections are identified according to Lóczy, D. (2012). II-VI = floodplain sections (river section I. has no floodplain); $1-5=$ rehabilitation potentials ( 1 = lowest; 5 = highest one).

As far as the rationalization of land use is concerned, it has to be kept in mind that following the great river regulations and even in the period between 1960 and 1980 an important objective of water management was the increase of arable land (by 25-30 per cent) and formation of large agricultural fields (up to 300 ha area) (Bognár, Gy. 1989). Nature conservation requirements have only been observed since the late 1980s. The land use map of the Kapos floodplain (Figure 4) shows that forests predominant in floodplain section II are replaced by agricultural land in section III; a balance is struck between land use classes in section IV, while grasslands occupy the largest area in $\mathrm{V}$ and in the embayments of section VI, where forests entirely disappear. In addition, the continuity of land use classes in the floodplain sections was described quantitatively (Table 5). It was found that in sections IV and V the buffer strip is continuous over almost one-third of the floodplain margin, which offers some protection against environmental pressure.
Interruption of this buffer zone by arable fields have to be eliminated in the future.

Floodplain areas critical for land use have been identified relying on the findings of soil mapping and land capability assessment. There are sections, e.g. the Koppány confluence area, where flood and excess water hazard is so high that in land use planning nature conservation has absolute priority over agricultural production. Arable farming should retreat to areas where excess water hazard is low. As a general guideline, because of their relative close association, land use classes can be made correspond to the main landform units (Table 6). In particular cases, however, exceptions can be made.

The land capability assessment only shows minor variations in land quality (Table 7), but it is striking that in both embayments studied former peat bogs (with Eutric Histosol) are least suitable for arable farming, while the chernozem meadow soils on loess (Mollic Gleysol) favour this type of land use. This finding has to be considered in the design of land use pattern. 

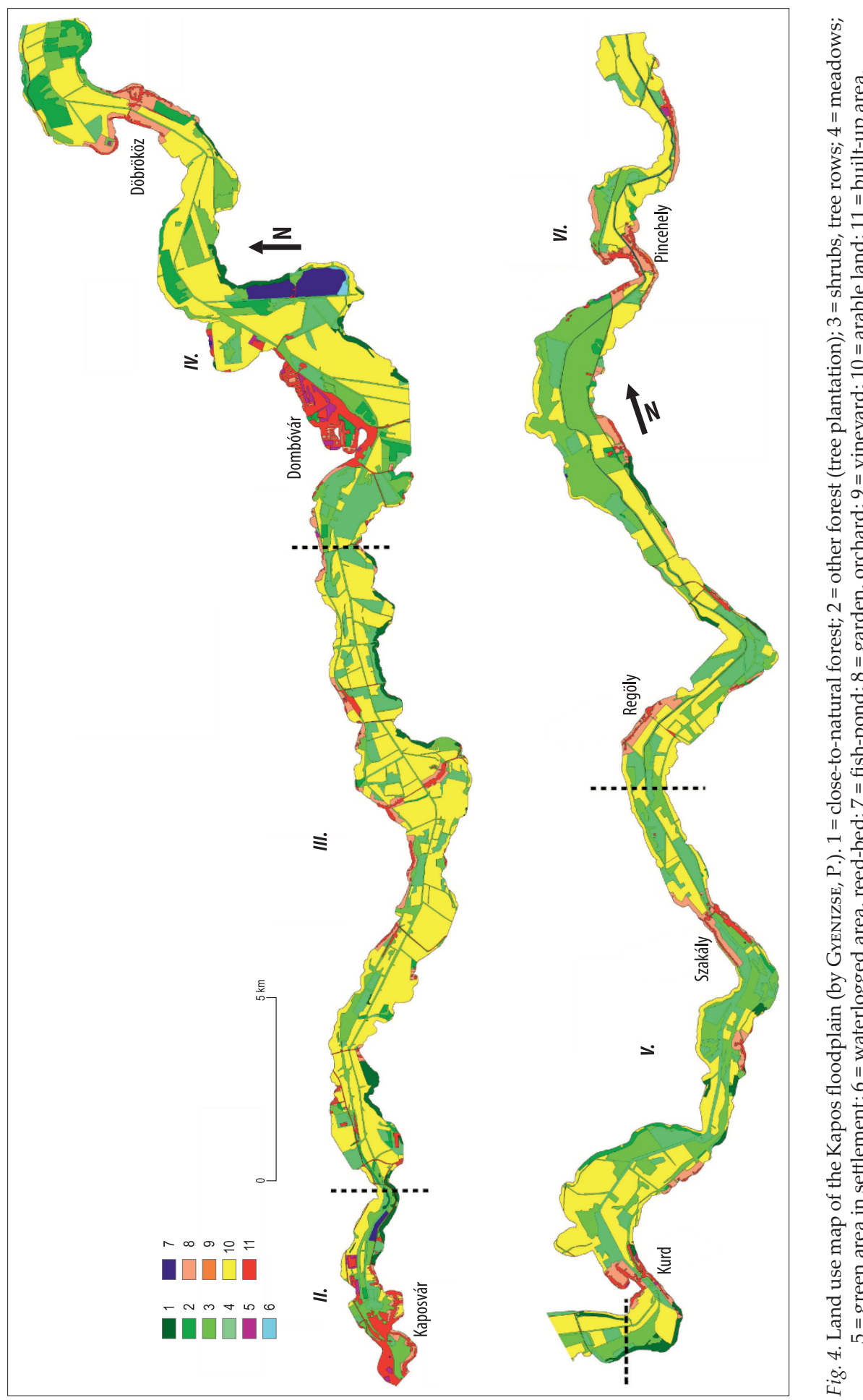
Table 5. Continuity of land use in the 100-m wide strip along the river in the different floodplain segments*

\begin{tabular}{l|c|c|c|c|c}
\hline \multirow{2}{*}{$\begin{array}{c}\text { Number of } \\
\text { segment }\end{array}$} & $\begin{array}{c}\text { Length of river } \\
\text { reach, } \mathrm{km}\end{array}$ & \multicolumn{2}{|c|}{$\begin{array}{c}\text { Area of marginal strip with } \\
\text { bushes and trees, } \mathrm{km}^{2}\end{array}$} & \multicolumn{2}{|c}{$\begin{array}{c}\text { Ratio of strips with close-to- } \\
\text { natural vegetation in the marginal } \\
\text { zone }\end{array}$} \\
\cline { 3 - 6 } & 17.7 & left-bank & right-bank & Total area, $\mathrm{km}^{2}$ & $\%$ \\
\hline III & 19.2 & 0.88 & 1.63 & 2.51 & 25.35 \\
IV & 21.3 & 1.19 & 2.14 & 3.34 & 30.38 \\
V & 28.2 & 1.12 & 2.07 & 3.19 & 30.31 \\
VI & 1.96 & 1.52 & 3.48 & 27.21 \\
\hline
\end{tabular}

${ }^{*}$ Compiled by Lóczy, D. 2019.

Table 6. Land use proposals for floodplain landforms of different elevation

\begin{tabular}{l|l|l}
\hline \multicolumn{1}{c|}{ Landforms } & \multicolumn{1}{|c}{ Frequency of inundation } & \multicolumn{1}{c}{ Proposed land use, economic activities } \\
\hline River terraces & $\begin{array}{l}\text { Flood-free, occasional excess water } \\
\text { from precipitation }\end{array}$ & $\begin{array}{l}\text { Built-up, arable, forest, grazing land, orchard, } \\
\text { hunting, gathering (mushrooms, forest fruits etc.) }\end{array}$ \\
\hline Natural levees & Rare and short-term inundation & $\begin{array}{l}\text { Orchard, horticulture, arable, forest, hunting, } \\
\text { gathering (mushrooms, forest fruits etc.) }\end{array}$ \\
\hline $\begin{array}{l}\text { Low floodplain } \\
\text { level }\end{array}$ & $\begin{array}{l}\text { Irregular inundation (in 5-10-year } \\
\text { intervals) }\end{array}$ & $\begin{array}{l}\text { Pasture, meadow, forest, fishing, growing me- } \\
\text { dicinal plants, hunting }\end{array}$ \\
\hline $\begin{array}{l}\text { Backswamps, aban- } \\
\text { doned channels }\end{array}$ & $\begin{array}{l}\text { Regular (seasonal) long-term in- } \\
\text { undation }\end{array}$ & $\begin{array}{l}\text { Reed-cutting, aquatic plants, waterfowl, hunting, } \\
\text { gathering (medicinal plants, dried flowers etc.) }\end{array}$ \\
\hline
\end{tabular}

Table 7. Assessment of overall land capability in the major embayments of the Kapos floodplain*

\begin{tabular}{|c|c|c|c|c|c|c|}
\hline \multirow{2}{*}{$\begin{array}{l}\text { Genetic soil } \\
\text { subtype or } \\
\text { variety }\end{array}$} & \multirow{2}{*}{$\begin{array}{c}\text { Approximate } \\
\text { WRB equivalent }\end{array}$} & \multirow{2}{*}{$\begin{array}{l}\text { Floodplain } \\
\text { landforms }\end{array}$} & \multirow[t]{2}{*}{ Main properties } & \multirow{2}{*}{$\begin{array}{l}\text { Soil parent } \\
\text { material }\end{array}$} & \multicolumn{2}{|c|}{$\begin{array}{c}\text { Soil } \\
\text { score }\end{array}$} \\
\hline & & & & & $\mathrm{A}$ & B \\
\hline $\begin{array}{l}\text { chernozem mead- } \\
\text { ow soil }\end{array}$ & Mollic Gleysol & $\begin{array}{l}\text { loess slope depos- } \\
\text { it along margins }\end{array}$ & \begin{tabular}{|l|} 
gentle slope, \\
medium deep \\
groundwater table
\end{tabular} & loess & 70 & 70 \\
\hline $\begin{array}{l}\text { 'humous carbon- } \\
\text { ate' soil on sand }\end{array}$ & $\begin{array}{l}\text { Mollic Arenosol, } \\
\text { Regosols }\end{array}$ & natural levees & $\begin{array}{l}\text { higher relief, } \\
\text { deeper ground- } \\
\text { water table }\end{array}$ & medium sand & 50 & 52 \\
\hline $\begin{array}{l}\text { meadow soil, } \\
\text { meadow alluvial } \\
\text { soil }\end{array}$ & $\begin{array}{l}\text { (Fluvi-mollic) } \\
\text { Gleysol }\end{array}$ & $\begin{array}{l}\text { medium flood- } \\
\text { plain level }\end{array}$ & $\begin{array}{l}\text { flat, seasonally } \\
\text { waterlogged }\end{array}$ & fine sand & 67 & 65 \\
\hline $\begin{array}{l}\text { boggy meadow } \\
\text { soil }\end{array}$ & Eutric Histosol & $\begin{array}{l}\text { oxbows, back- } \\
\text { swamps }\end{array}$ & $\begin{array}{l}\text { low position, } \\
\text { waterlogged }\end{array}$ & $\begin{array}{l}\text { calcareous silt } \\
\text { with muck }\end{array}$ & 48 & 48 \\
\hline $\begin{array}{l}\text { earthy peat ('black } \\
\text { earth') }\end{array}$ & Humic Histosol & backswamps & $\begin{array}{l}\text { low position, } \\
\text { waterlogged }\end{array}$ & $\begin{array}{l}\text { calcareous silty } \\
\text { clay }\end{array}$ & 58 & 57 \\
\hline
\end{tabular}

*Compiled by Lóczy, D. 2019. A = Döbrököz-Csibrák embayment; B = Szakály-Keszőhidegkút embayment.

\section{Conclusions}

The proposed changes in floodplain land use could have beneficial effects even on the short run. The damage caused by flooding would be reduced and floodwater retention enhanced. Over an undeveloped and vegetated floodplain floodwater can spread out without major damage and can be stored in floodplain soils and landforms before it evaporates. The 
biggest challenge of successful restoration of the wetlands, however, is the raising of the groundwater levels. Silt layers of low permeability in the floodplain may reduce infiltration. However, the incised Kapos and Koppány canals drain groundwater from the underlying layers of coarse sands inherited from high-energy braided system active in Late Pleniglacial and at the beginning of the Late Glacial.

Afforestation is desirable in the higher levels of the Kapos floodplain since the roots of arboreous vegetation promote infiltration, recharge groundwater and store moisture in multi-fold higher amounts than the soils of arable fields or meadows. At the same time, the trees and herbaceous plants of the riparian zone transfer huge amounts of water from the floodplain to the atmosphere by transpiration and reduces flood wave crests. This contradicts the river engineers' view who are critical about floodplain roughness and flood protection infrastructure and claim that higher retention in a floodplain forest could lead locally to raised groundwater tables. For restoration projects a certain freeboard at dykes has to be permitted to secure local flood protection.

Through improving connectivity and water availability floodplain biodiversity could also be enhanced and the nature conservation function strengthened. In the backswamps arable farming should be replaced by meadows connected to the ecological network and gallery forests along watercourses.

Arable (or possibly organic) farming should be restricted to higher-lying, terracelike surfaces with minimum excess water inundation hazard, favourable soil properties and water availability (ÖKO Rt., FÖMI and VÍZPART Kft. 2000). Although the marginal floodplain zone with washed-down loess veneer ('higher floodplain level') is suitable for arable farming, the intensity of cultivation has to be kept within limits even here and a buffer zone has to be excluded from intensive cultivation. In arable fields of poor productivity cereal and oil crop growing should be gradually replaced by the cultivation of or horticultural crops (e.g. horse raddish, which has some tradition in the region), while the lowest-lying tracts could be used for medicinal plants, as meadows or forests - with regard to landscape ecological consideration.

The main goals of rehabilitation should be flood control also including temporal floodwater retention (subordination of land use to flood control); improvement of landscape pattern (providing connections in all directions); increasing the effectiveness of buffer zones in order to reach better river water quality and establishing a floodplain economy in harmony with nature conservation considerations.

Future research should exploit the advantages offered by a systematic hydromorphological survey and hydraulic modelling for a more precise definition of the sites and tasks of restoration with purposes of flood control as well as the establishment of ecological corridors and buffer strips.

Acknowledgements: Authors are grateful to the Hungarian National Scientific Fund (OTKA, contract number K 104552), the GINOP-2.3.2.15-2016-00055 research fund and the Programme Excellence in Higher Education Institutions 2019, Topic II. 3. ("Innovation for sustainable life and environment") for financial support.

\section{REFERENCES}

APFM-WMO 2017. Selecting measures and designing strategies for integrated flood management. Associated Programme on Flood Management. Geneva, World Meteorological Organization.

BALL, T. 2008. Management approaches to floodplain restoration and stakeholder engagement in the UK: A survey. Ecohydrology and Hydrobiology 8. (2): 273-280. Doi: 10.2478/v10104-009-0021-0

Bencze, G. 2000. Vízimunkálatok a Sió-Kapos-Sárvíz vízrendszerén a XVIII-XIX. században (Water management measures in the Sió-Kapos-Sárvíz river system in the $18-19^{\text {th }}$ centuries). Honismeret 28. (2): 99-101. Available at http://www.vjrktf.hu/carus/ honisme/ho000222.htm

Bernhardt, E.S., Palmer, M.A., Allan, J.D., Alexander, G., Barnas, K., Brooks, S., Carr, J., Clayton, S., Dahm, C., Follstad-Shah, J., Galat, D., Gloss, S., Goodwin, P., Hart, D., Hassett, B., Jenkinson, R., Katz, S., Kondolf, G.M., LaKe, P.S., Lave, R., Meyer, J.L., O’Donnell, T.K., Pagano, L., Powell, B. and Sudduth, E. 2005. Synthesizing U.S. river restoration efforts. Science 308. (5722): 636-637. Doi: 10.1126/science.1109769 
Beszédes, J. and Herman, J. 1829. Kapos mocsárainak Plánuma... (Plan of swamps along the Kapos River...). Manuscript map. Kaposvár, Hungary, Somogy County Archive.

BogÁrd, J. 1971. Vízfolyások hordalékszállitása (Sediment transport of watercourses). Budapest, Akadémiai Kiadó. (in Hungarian)

Bogárdi, I. and BALOGH, E. 2014. Floodway system operation along levee-protected rivers. Journal of Water Resources Planning and Management 140. (8): Doi: 10.1061/(ASCE)WR.1943-5452.0000391

Bognár, Gr. (ed.) 1989. Vízfolyások környezetbe illő szabályozása (Stream regulation by setting in the environment). Budapest, VITUKI.

Bratrich, C., Truffer, B. and Wehrli, B. 2002. River restoration projects - understanding success and failure. Report to the NCEAS National River Restoration Synthesis (NRRS) working group meeting in 14 September 2002. 1-13.

Brierley, G.J., Fryirs, K.A., Outhet, D. and Massey, C. 2002. Application of the River Styles framework as a basis for river management in New South Wales, Australia. Applied Geography 22. 91-122. Doi: 10.1016/ S0143-6228(01)00016-9

Brierley, G.J. and Fryirs, K.A. 2008. River futures. an integrative scientific approach to river repair. The Science and Practice of Ecological Restoration Series. Washington, D.C., Island Press.

BRookes, A. 1996. Floodplain restoration and rehabilitation. In Floodplain Processes. Eds.: Anderson, M.G., Walling, D.E. and Bates, P.D., Chichester, John Wiley and Sons, 553-576.

Brookes, A. and Shields, F.D. Jr. (eds.) 1996. River Channel Restoration: Guiding Principles for Sustainable Projects. Chichester, John Wiley \& Sons.

Brooks, A.P. and Brierley, G.J. 2004. Framing realistic river rehabilitation targets in light of altered sediment supply and transport relationships: lessons from East Gibbsland, Australia. Geomorphology 58. (1-4): 107-123.

Buijse, A.D., Coops, H., Staras, M., Jans, L.H., van Geest, G.J., Grift, R.E., Ibelings, B.W., Oosterberg, W. and Roozen, F.C.J.M. 2002. Restoration strategies for river floodplains along large lowland rivers in Europe. Freshwater Biology 47. 889-907. Available at https://doi.org/10.1046/j.1365-2427.2002.00915.x

Bullock, A. and Acreman, M.C. 2003. The role of wetlands in the hydrological cycle. Hydrology and Earth System Science 7. (3): 358-389. Doi: 10.5194/ hess-7-358-2003

Clarke, S.J., Bruce-Burgess, L. and Wharton, G. 2003. Linking form and function: towards an eco-hydromorphic approach to sustainable river restoration. Aquatic Conservation: Marine and Freshwater Ecosystems 13. 439-450.

Dezsô, J., Lóczy, D., Salem, A.M. and Nagy, G. 2019. Floodplain connectivity. In The Drava River: Environmnetal Problems and Solutions. Ed.: Lóczy,
D., Cham, Switzerland, Springer, 215-230. Doi: 10.1007/978-3-319-92816_14

Didovets, I., Krysanova, V., Bürger, G., Snizhko, S., Balabukh, V. and Bronstert, A. 2019. Climate change impact on regional floods in the Carpathian region. Journal of Hydrology: Regional Studies 22. 1-14. Doi: 10.1016/j.ejrh.2019.01.002

Dostal, T., Valentová, J., Weyskrabova, L., Koudelka, P., David, V. and Valenta, P. 2012. Retention and flood control effects of floodplains. Proceedings, $9^{\text {th }}$ International Symposium on Ecohydraulics, Vienna, 17-21 September 2012. Available at http://www. ise2012.boku.ac.at/papers/16172_2.pdf

Downs, P. and Thorne, C.R. 2000. Rehabilitation of a lowland river: Reconciling flood defence with habitat diversity and geomorphological sustainability. Journal of Environmental Management 58. (4): 249-268. Doi: 10.1006/jema.2000.0327

DöмsöDı, J. 1980. A hazai tőzeglápok (tőzegek) osztályozása (Classification of peat bogs in Hungary). Földrajzi Értesítő / Hungarian Geographical Bulletin 29. (3-4): 485-494. (in Hungarian with English summary)

DömsöDi, J. 2011. Földminősités és földértékelés (Land assessment and evaluation). Budapest, Szent Gellért Kiadó. (in Hungarian with English summary)

DWORAK, T. 2008. Flood risk management and floodplain restoration in Europe: recent policy developments at EU level. In Restoring Floodplains in Europe. Eds. Moss, T. and Mondstadt, J., London, IWA Publishing, 47-60.

ECRR 2001. River restoration in Europe. Conference on River Restoration, Proceedings. Institute for Inland Water Management and Waste Water Treatment (RIZA), Riza report 2001.023. Lelystad, The Netherlands, RIZA. Available at http://distance. ktu.lt/kbridge/IRBM/Unit1_2/resources/documents/ Annex1_1.2F.pdf

Fenér, Z.Zss. and Rakonczai, J. 2019. Analysing the sensitivity of Hungarian landscapes based on climate change induced shallow groundwater fluctuation. Hungarian Geographical Bulletin 68. (4): 355-372. Doi: 10.15201/hungeobull.68.4.3.

Fennessy, M.S. and Cronk, J.K. 1997. The effectiveness and restoration potential of riparian ecotones for the management of nonpoint source pollution, particularly nitrate. Critical Reviews in Environmental Science and Technology 27. 285-317.

Fischer, K.J. 1994. Fluvial geomorphology and flood control strategies: Sacramento River, California. In The variability of large alluvial rivers. Eds.: Sснимм, S.A. and WinkLeY, B.R., New York, ASCE Press, 115-139.

FISRW 1998. Stream Corridor Restoration - Principles, Practices and Processes. Subdocument 57.6/2:EN3/ PT.653. Federal Interagency Stream Restoration Working Group, Washington, D.C., U.S. Department of Agriculture.

Fryirs, K.A. and Brierley, G.J. 2016. Assessing the geomorphic recovery potential of rivers: forecasting 
future trajectories of adjustment for use in management. Water 3. (5): 727-748. Doi: 10.1002/wat2.1158

Gallant, J.C. and Dowling, T.I. 2003. A multiresolution index of valley bottom flatness for mapping depositional areas. Water Resources Research 39. 1347-1353. Doi: 10.1029/2002WR001426

Gergely, E., Géczi, Cs., Horváth, J., Jakab, A., Jónás, Gy.-né, Károlyi, Z.-Né, Mattányi, Zs., Szalai, Z., Szabó, I. and Ress, S. 2000. Kapos folyóvölgy Lehetôségterv (Kapos river valley - Feasibility plan). Budapest, Öko Zrt.

Guerrin, J. 2014. A floodplain restoration project on the River Rhône (France): analyzing challenges to its implementation. Regional Environmental Change 15. (3): 559-568. Doi: 10.1007/s10113-014-0650-8

GWP-WMO 2012. Conservation and Restoration of Rivers and Floodplains. Associated Programme on Flood Management, Global Water Partnership, Stockholm. Integrated Flood Management Tool Series. Geneva, World Meteorological Organization. Available at https://www.floodmanagement.info/publications/ tools/APFM_Tool_13.pdf ()

Hein, T., Schwarz, U., Habersack, H., Nichersu, I., Preiner, S., Willby, N. and Weigelhofer, G. 2016. Current status and restoration options for floodplains along the Danube River. Science of the Total Environment 543. (A): 778-790. Doi: 10.1016/j. scitotenv.2015.09.073.

Hey, D.L. and Philippi, N.S. 1995. Flood reduction through wetland restoration: The Upper Mississippi River Basin as a case history. Restoration Ecology 3. (1): 4-17. Doi: 10.1111/j.1526-100X.1995.tb00070.x

Hohausova, E. and Jurajda, P. 2005. Restoration of a river backwater and its influence on fish assemblage. Czech Journal of Animal Science 50. (10): 473-482.

Holmes, N.T.H. 1998. Floodplain Restoration. In United Kingdom Floodplains. Eds.: BAILEY, R.G., Jose, P.V. and Sherwood, B.R., Otley, UK, Westbury Publishing, 29-41.

Hulse, D. and Gregory, S. 2004. Integrating resilience into floodplain restoration. Urban Ecosystems 7. (3): 295-314. Doi: 10.1023/B:UECO.0000044041.94705.52

Kauffman, J.B. and Beschta, R.L. 1997. An ecological perspective of riparian and stream restoration in the Western United States. Fisheries 22. (3): 12-24.

Kertész, Á. and KřečeK, J. 2019. Landscape degradation in the world and in Hungary. Hungarian Geographical Bulletin 68. (3): 201-221. Doi: 10.15201/ hungeobull.68.3.1.

KiedrzyŃsKa, E., KiedrzyŃsKi, M. and ZALewsKi, M. 2015. Sustainable floodplain management for flood prevention and water quality improvement. Natural Hazards 76. 955-977. Doi: 10.1007/s11069-014-1529-1

KLIne, M. 2007. River Corridor Planning Guide to Identify and Develop River Corridor Protection and Restoration Projects. Draft. Vermont River Management Program. Waterbury, VT, Vermont Agency of Natural Resources.
KLUG, H. 2016. Bodenfunktionen und Hochwasserentstehung. In Der Wert des Bodens in der Wasser-wirtschaft. Vorstellung des ÖWAVArbeitsbehelfs 47 ,Bodenfunktionen in der Wasserwirtschaft". Wien, Österreichischer Wasserund Abfallwirtschaftsverband (ÖWAV).

Kondolf, G.M. and Micheli, E.R. 1995. Evaluating stream restoration projects. Environmental Management 19. (1): 1-15. Doi: 10.1007/BF02471999

Kronvang, B., Larsen, S.E., Jensen, J.P., Andersen, H.E., LÁzÁr, A. and FéHer, J. 2004. Catchment report: Kapos, Hungary. Trend analysis, retention and source apportionment. EUROHARP report 7-2004, NIVA report SNO 4790-2004. Oslo, Norway, EUROHARP-NIVA.

Larsen, E.W., Girvetz, E.H. and Fremier, A. 2006. Assessing the effects of alternative setback levee scenarios employing a river meander migration model. Environmental Management 37. (6): 880-897. Doi: 10.1007/s00267-004-0220-9

Lóczy, D. 2013. Hydromorphological-geoecological foundations of floodplain management: Case study from Hungary. Saarbrücken, Lambert Academic Publishing.

Lóczy, D., Pirkhoffer, E. and Gyenizse, P. 2012. Geomorphometric floodplain classification in a hill region of Hungary. Geomorphology 147-148. 61-72. Doi: 10.1016/j.geomorph.2011.06.040

Macdonald, K.B. and Weinmann, F. (eds.) 1997. Wetland and riparian restoration: Taking a broader view. Report EPA910-R-97-007. Seattle, WA, U.S. Environmental Protection Agency.

McHarg, I. 1969. Design with Nature. Graden City, NY, Natural History Press. New edition: 1995. New York, John Wiley and Sons.

MadDock, I. 1999. The importance of physical habitat assessment for evaluating river health. Freshwater Biology 41. 373-391. Doi: 10.1046/j.13652427.1999.00437.x

MANCI, K.M. 1989. Riparian ecosystem creation and restoration: a literature summary. US Fish and Wildlife Service Biological Report 89. (20). Available at http://pubs.er.usgs.gov/publication/70122966

Moss, T. and Monstadt, J. (eds.) 2008. Restoring Floodplains in Europe. Policy Contexts and Project Experiences. London, IWA Publishing.

National Research Council 1992. Restoration of Aquatic Ecosystems. Washington, D.C., National Academy Press. Available at http://www.nap.edu/cata$\log / 1807 . h t m l$

Newson, M.D. and Large, A.R.G. 2006. 'Natural' rivers, 'hydromorphological quality' and river restoration: a challenging new agenda for applied fluvial geomorphology. Earth Surface Processes and Landforms 31. 1606-1624. Doi: 10.1002/esp.1430

Nunnally, N.R. 1978. Stream renovation: An alternative to channelization. Environmental Management 2. 403-411. Doi: 10.1007/BF01872915 
Opperman, J.J., Moyle, P.B., Larsen, E.W., Florsheim, J.L. and Manfree, A.D. 2017. Floodplains: Processes and Management for Ecosystem Services. Oakland, CA, University of California Press.

ÖKO Rt., FÖMI and VÍZPART Kft. 2000. A magyarországi folyók töltésezett szakaszán kialakult hullámterek területhasználatának jellemzése (Description of land use in the active floodplains of channelized rivers in Hungary). Report. Budapest, Office for Nature Conservation, Ministry of Environment.

PálfaI, I. 2009. Inland flooding in Hungary. Riscuri şi catastrophe 8. (7): 193-201.

Petrasovits, I. and Balogh, J. 1975. Növénytermesztés és vízgazdálkodás (Crop cultivation and water management). Budapest, Mezőgazdasági Kiadó.

Petts, G.E., Möller, H. and Roux, A.L. (eds.) 1989. Historical Change of Large Alluvial Rivers: Western Europe. Chichester, John Wiley and Sons.

Piégay, H., Darby, S.E., Mosselman, E. and Surian, N. 2005. A review of techniques available for delimiting the erodible river corridor: a sustainable approach to managing bank erosion. River Research and Applications 21. (7): 773-789. Doi: 10.1002/rra.881

Posthumus, H., Hewett, C.J.M., Morris, J. and Quinn, P.F. 2008. Agricultural land use and flood risk management: engaging with stakeholders in North Yorkshire. Agricultural Water Management 95. (7): 787-798. Doi: 10.1016/j.agwat.2008.02.001

Rakonczai, J., Csató, Sz., Mucsi, L., Kovács, F. and SzATMÁri, J. 2003. Az 1999. és 2000. évi alföldi belvízelöntések kiértékelésének gyakorlati tapasztalatai (Experiences from the evaluation of the 1999 and 2000 excess water inundations in the Great Hungarian Plain). Vízügyi Közlemények, Special Issue 4. 317-336.

Rogger, M., Agnoletti, M., Alaoui, A., Bathurst, J.C., Bodner, G., Borga, M., Chaplot, V., Gallart, F., Glatzel, G., Hall, J., Holden, J., Holko, L., Horn, R., Kiss, A., Kohnová, S., Leitinger, G., Lennartz, B., Parajka, J., Perdigão, R., Peth, S., Plavcová, L., Quinton, J.N., Robinson, M., Salinas, J.L., Santoro, A., Szolgay, J., Tron, S., van den AKker, J.J.H., Viglione, A. and Blöschl, G. 2017. Land use change impacts on floods at the catchment scale: Challenges and opportunities for future research. Water Resources Research 53. WR020723. Doi: 10.1002/2017WR020723

Rohde, S., Hostmann, M., Peter, A. and Ewald, K.C. 2006. Room for rivers: an integrative search strategy for floodplain restoration. Landscape and Urban Planning 78. 50-70. Doi: 10.1016/j.landurbplan.2005.05.006

Roni, P. and Beechie, T. 2013. Stream and Watershed Restoration: A Guide to Restoring Riverine Processes and Habitats. New York, Wiley-Blackwell.

Roni, P., Hall, J.E., Drenner, S.M. and Arterburn, D. 2019. Monitoring the effectiveness of floodplain habitat restoration: A review of methods and recommendations for future monitoring. WIREsWater 6. (4): e1355. Doi: 10.1002/wat2.1355
Schneider, E. 2010. Floodplain restoration of large European rivers, with examples from the Rhine and the Danube. In Restoration of Lakes, Streams, Floodplains, and Bogs in Europe. Wetlands: Ecology, Conservation and Management 3. Ed.: Eiseltová, M., Dordrecht, Springer, 185-223. Doi: 10.1007/978-90481-9265-6_11

Schwarz, U. 2013. Assessment of the Restoration Potential in the Transboundary UNESCO Biosphere Reserve MuraDrava-Danube. Vienna, WWF Austria.

SEAR, D. 1994. River restoration and geomorphology. Aquatic Conservation: Marine and Freshwater Ecosystems 4. 169-177. Doi: 10.1002/aqc.3270040207

SŁowıK, M. 2013. Transformation of a lowland river from a meandering and multi-channel pattern into an artificial canal: retracing a path of river channel changes (the Middle Obra River, W-Poland). Regional Environmental Change 13. 1287-1299. Doi: 10.1007/ s10113-013-0453-3

SŁowik, M., Dezső, J., Kovác, J. and GaŁka M. 2020. The formation of low-energy meanders in loess landscapes (Transdanubia, Central Europe). Global and Planetary Change 184. 103071. Doi: 10.1016/j. gloplacha.2019.103071

Smith, M.P., Schiff, R., Olivero, A. and MacBroom, J. 2008. The Active River Area: A Conservation Framework for Protecting Rivers and Streams. Boston, MA, The Nature Conservancy. Available at. http://www. floods.org/PDF/ASFPM_TNC_Active_River_Area. pdf

SomLyódi, L. (ed.) 2011. Magyarország vízgazdálkodása: helyzetkép és stratégiai feladatok (Water management in Hungary: state of the art and strategic tasks). Budapest, Hungarian Academy of Sciences.

Theiling, CH. 1998. Floodplain geomorphology and river habitat. Chapter 4, River Restoration. Reston, VA, U.S. Geological Survey. Available at http://www. umesc.usgs.gov/documents/reports/1999/status_ and_trends/99t001_ch04lr.pdf

Tockner, K., Schiemer, F., Baumgartner, C., Kum, G., Weigand, E., Zweimuller, I. and Ward, J.V. 1999. The Danube restoration project: species diversity patterns across connectivity gradients in the floodplain system. Regulated Rivers: Research and Management 15. 245-258.

Tockner, K. and StAnford, J.A. 2002. Riverine flood plains: present state and future trends. Environmental Conservation 29.308-330. Doi: 10.1017/ S037689290200022X

U.S. Department of Commerce 1998. Stream Corridor Restoration: Principles, Processes, and Practices. Springfield, VA, US Department of Commerce. Available at http://www.nrcs.usda.gov/technical/ stream_restoration/newtofc.html

Verhoeven, J.T.A. and Setter, T.L. 2010. Agricultural use of wetlands: opportunities and limitations. Annals of Botany 105. 155-163. Doi: 10.1093/aob/ mcp172 
Wheaton, J.M., Fryirs, K.A., Brierley, G.J., Bangen, S.G., Bouwes, N. and O'Brien, G. 2015. Geomorphic mapping and taxonomy of fluvial landforms. Geomorphology 248. 273-295. Doi: 10.1016/j.geomorph.2015.07.010

Wheaton, J.M., BennetT, S.N., Bouwes, N., Camp, R., Maestas, J.D. and Shahverdian, S.M. 2019. Principles of low-tech process-based restoration. In Low-Tech Process-Based Restoration of Riverscapes: Design Manual. Eds.: WheAton, J.M., BennetT, S.N., Bouwes, N., Maestas, J.D. and Shahverdian, S.M., Logan, UT, Utah State University Restoration Consortium, 1-31.

Wissmar, R.C. and Beschta, R.L. 1998. Restoration and management of riparian ecosystems a catchment perspective. Freshwater Biology 40. 571-585. Doi: 10.1046/j.1365-2427.1998.00383.x

WWF 2004. Living with floods. Achieving ecologically sustainable flood management in Europe. Policy Briefing. Brussels, World-Wide Fund for Nature, European Policy Office. Available at http://wwf.panda.org/ about_wwf/where_we_work/europe/what_we_do_」 policy_and_events/epo/initiatives/freshwater.cfm
WWF International 2010. Assessment of the restoration potential along the Danube and main tributaries. Working paper for the Danube River Basin. Final Draft. Vienna, World-Wide Fund for Nature. Available at http://assets.panda.org/downloads/wwf_restoration_potential_danube.pdf

XIE, H.L., Huang, Y.Q., Chen Q.R., Zhang, Y.W. and Wu, Q. 2019. Prospects for agricultural sustainable intensification: A review of research. Land 8. 157-184. Doi: 10.3390/land8110157

ZöCKLER, C. 2000. Wise Use of Floodplains - review of restoration projects in a number of European countries. WWF European Freshwater Programme. Cambridge, UK, WWF. Available at http://www.panda.org/downloads/europe/RiverRestoration.pdf 